\title{
Regulation of Candida albicans Hyphal Morphogenesis by Endogenous Signals
}

\author{
Daniel Kornitzer \\ Department of Molecular Microbiology, B. Rappaport Faculty of Medicine, Technion-Israel Institute of \\ Technology, Haifa, Israel; danielk@technion.ac.il
}

Received: 10 January 2019; Accepted: 26 February 2019; Published: 28 February 2019

\begin{abstract}
Candida albicans is a human commensal fungus that is able to assume several morphologies, including yeast, hyphal, and pseudohyphal. Under a range of conditions, C. albicans performs a regulated switch to the filamentous morphology, characterized by the emergence of a germ tube from the yeast cell, followed by a mold-like growth of branching hyphae. This transition from yeast to hyphal growth has attracted particular attention, as it has been linked to the virulence of C. albicans as an opportunistic human pathogen. Signal transduction pathways that mediate the induction of the hyphal transcription program upon the imposition of external stimuli have been extensively investigated. However, the hyphal morphogenesis transcription program can also be induced by internal cellular signals, such as inhibition of cell cycle progression, and conversely, the inhibition of hyphal extension can repress hyphal-specific gene expression, suggesting that endogenous cellular signals are able to modulate hyphal gene expression as well. Here we review recent developments in the regulation of the hyphal morphogenesis of C. albicans, with emphasis on endogenous morphogenetic signals.
\end{abstract}

Keywords: Candida albicans; hyphae; morphogenesis; cell cycle; transcription

\section{Introduction}

Candida albicans is a human commensal organism found in the gastrointestinal tract and other mucosal surfaces of a majority of the population [1-3]. It can cause superficial mucosal infections in immunocompetent individuals, but among immunocompromised or debilitated patients, it can be responsible for life-threatening systemic disease [4]. In the United States, $9 \%$ of nosocomial bloodstream infections are caused by Candida spp. [5,6], of which $40 \%-70 \%$ are caused by C. albicans, and the rest by other Candida species [7,8]. Bloodstream infection, or candidemia, develops into deep-seated candidiasis when the fungus invades internal organs [9]. The mortality rate for invasive candidiasis has remained stubbornly high at $30 \%-40 \%$ over the last several decades in spite of the introduction of new classes of antifungals such as the echinocandins [6,8,10-14]. Candidiasis is currently responsible for an estimated 700,000 annual deaths worldwide [15].

C. albicans has been historically distinguished from other Candida species by its ability to switch between a yeast form of growth, with rounded cells that disperse after septation; a pseudohyphal form, characterized by chains of elongated yeast cells; and a hyphal, or mold form, characterized by branching chains of tubular cells without constrictions at the sites of septation [16]. While most other Candida species are only able to form yeast and pseudohyphae (reviewed in Reference [17]), C. dubliniensis and C. tropicalis, the Candida species most closely related to C. albicans, are nonetheless also able to form true hyphae, albeit less efficiently and under a more restricted range of conditions $[18,19]$. Recently, the emerging pathogen C. auris was found to form hyphae as well, but only after passage in an animal host [20]. 
Several environmental stimuli can promote the switch from yeast to hyphal growth in C. albicans. Incubation in serum at $37^{\circ} \mathrm{C}$ is a potent stimulus and provides the basis for a diagnostic test for C. albicans in the clinical laboratory. Other environmental stimuli that are known to promote the switch to hyphal growth in $\mathrm{C}$. albicans include neutral or alkaline $\mathrm{pH}$, carbon starvation, nitrogen starvation, cell density via quorum sensing molecules, low oxygen and elevated $\mathrm{CO}_{2}$, and the presence of $\mathrm{N}$-acetylglucosamine (GlcNAc) (reviewed in References [21,22]).

\section{The Role of Hyphal Morphogenesis in the Virulence of $C$. albicans}

The observation that $C$. albicans is found predominantly in the hyphal form in tissue samples of candidiasis patients [23] suggests that the yeast-to-hyphal morphogenetic switch plays a role in the transition from candidemia to the subsequent tissue invasion. The establishment of candidemia itself might also be aided by the enhanced ability of the hyphal morphology to penetrate the mucous membranes and underlying tissues, and to enter the bloodstream [24]. Furthermore, the hyphae formation in the phagosome was shown to contribute to the ability of $C$. albicans cells to escape phagocytosis and kill the macrophage [25-27]. Finally, optimal biofilm formation on synthetic substrates, an ability that enables C. albicans to colonize indwelling devices and cause iatrogenic candidemia, is highly correlated with the capacity of the strain to form hyphae [28]. Animal models of infection provide support for the role of the yeast to hyphal transition in pathogenesis. In a mouse model of systemic infection, C. albicans mutants that are unable to switch from the yeast form to the hyphal form demonstrate significantly reduced virulence [29,30]. Studies of strains engineered so that the yeast-to-hyphal switch can be regulated in vivo suggested that hyphal morphogenesis after injection into the bloodstream is essential for virulence $[29,31]$ while inhibiting hyphal morphogenesis early in the infection significantly increased the survival of the host [32]. Whereas a genomic screen to identify determinants of hyphal growth and/or virulence in mice revealed only a partial overlap [33], a more recent global analysis reaffirmed the link between hyphal morphogenesis and virulence by showing that among 177 mutant strains tested for virulence in mice, attenuation of virulence was significantly correlated with decreased hyphal morphogenesis [34]. On the other hand, most studies and observations appear to support a strong link between hyphal morphogenesis and C. albicans pathogenicity $[35,36]$.

Mucosal infections that affect both healthy and immunosuppressed individuals include oral candidiasis and vulvovaginal candidiasis, whereas esophageal candidiasis occurs in patients with chronic diseases [37]. These types are much more prevalent than systemic candidiasis and, although usually less threatening than invasive disease, can impose a significant burden on patients [38]. These superficial infections appear to involve the yeast-to-hyphal transition as well [39-42].

\section{Mechanism of Hyphal Morphogenesis}

The two main fungal morphologies, yeast and hyphae, are distinguished by a different polarization of cellular growth. In both cases, the growth is differentially distributed: in hyphae, the growth is concentrated at the tip of the extending filament, and in yeast, the growth occurs mainly in the bud and the daughter cell, and very little in the mother cell. However, in contrast to hyphal growth which occurs permanently at the apex, the yeast bud only maintains apical growth in the initial stages after emergence from the mother cell, after which it switches to isotropic growth, lending the cell its final oval morphology. The transition from apical to isotropic growth in the yeast bud is best understood in the baker's yeast $S$. cerevisiae, where it depends on the sequential activation of the different cyclin-cyclin-dependent kinase (CDK) complexes involved in the cell cycle progression [43]. In the early bud, the activity of the G1 cyclins Cln1 and Cln2 promotes focused apical growth by concentrating the activity of the small GTPase Cdc42 at the bud tip, which induces a polarization of the actin cytoskeleton towards the tip, whereas in G2, activation of the mitotic cyclins causes a switch from apical to diffuse isotropic growth and the delocalization of Cdc42 from the bud tip (reviewed in Reference [44]). It was, therefore, suggested that the difference between the yeast and hyphal 
modes of growth in polymorphic fungi such as C. albicans can be reduced largely to a difference in the polarization of the actin cytoskeleton [45].

In filamentous fungi, the localization of cellular growth into a small area of the cell surface at the hyphal apex requires strong polarization of the cellular biosynthetic machinery, involving a large-scale movement of vesicles containing membranes and cell wall precursors towards the hyphal tip (recently reviewed in References $[46,47]$ ). This movement depends on both the microtubule and the actin cytoskeleton, and is coordinated by a vesicle organizing center located just behind the hyphal tip: the Spitzenkörper. The rapid exocytosis of the transported vesicles drives hyphal tip elongation. This exocytosis must be counterbalanced by endocytosis in order to recuperate excess membranes and membrane-anchored enzymes that participate in cell wall biosynthesis $[48,49]$. A collar of endocytic actin patches surrounds the hypha subapically, suggesting a tight coupling between apical exocytosis and subapical endocytosis [50]. Although the mechanics of hyphal elongation are thought to be broadly similar in C. albicans hyphal cells and in filamentous fungi, there are, nonetheless, some significant differences: for example, the C. albicans hyphae extension is relatively slower and does not appear to require microtubules, although it does still require the actin cytoskeleton [51,52]. Furthermore, while $C$. albicans hyphae also have a Spitzenkörper near the apex [53], a recent report concludes that the travel of most secretory vesicles is short-range, compared to that in typical filamentous fungi [54].

The establishment and maintenance of polarization of the hyphal cytoskeleton require polarity markers at the hyphal apex. As in other fungi, a protein complex called polarisome forms a cap at the site of growth in C. albicans hyphae, as well as in yeast and pseudohyphal cells [53]. Compared to the Spitzenkörper, the hyphal polarisome proteins show much less turnover [55]. The polarisome recruits the formin Bni1, which, in turn, may stimulate actin polymerization at the hyphal tip [56,57]. Polarized growth in C. albicans, like in many cell types, also requires several small GTPases such as Cdc42 [58,59] and other Ras-like proteins (reviewed in Reference [60]). The regulation of Cdc42 activity and localization by the activity of its GTP exchange factor Cdc24 and by its GTPase-activating proteins Rga2 and Bem3 are thought to be central to the regulation of hyphal morphogenesis [61,62]. Another small GTPase, Rsr1, is also required for the maintenance of the polar localization of Cdc42 [63]. In particular, Rsr1 is required for the contact-dependent (thigmotropic) directionality of hyphal growth: in its absence, hyphae lose their ability to follow the contour of solid growth surfaces $[64,65]$.

\section{Induction of the Hyphal Morphogenesis of C. albicans by External Stimuli}

Several signal transduction regulators, notably components of the MAPK- [66] and cAMP/PKAdependent pathways $[67,68]$, can mediate the yeast-to-hyphal switch. Hyphal morphogenesis is accompanied by the increased expression of a large number of genes $[69,70]$, and many transcription factors (TFs) have been identified that can influence filamentous growth, including Cph1 [71], Efg1 [30,72], Cph2 [73], Czf1 [74], Tec1 [75], Rim101 [76], Hms1 [77], Tup1 [78], Nrg1 [79], Flo8 [80], Brg1/Gat2 [81], Mcm1 [82], Fkh2 [83] and Ume6 [84,85]. Deletions of the genes encoding these TFs exhibited reduced filamentous growth (or, in the case of the transcriptional repressors Nrg1 and Tup1, enhanced filamentous growth). While mutants of some TFs such as Efg1 are defective in hyphal morphogenesis induced by many conditions, the effect of the deletion of many of these TFs is only detectable under specific induction conditions. This suggests that specific TFs can be activated by specific signaling pathways and, indeed, several of these TFs are direct targets of hyphal-inducing signal transduction pathways $[66,86,87]$. The transcription program that accompanies the yeast-to-hyphal switch also varies according to the mode of hyphal induction $[69,70,88]$. However, a "core" set of induced genes common to many hyphal induction modes can be defined, which includes genes encoding hyphal cell surface components such as the Hwp1 and Als3 proteins, and the cytolytic toxin Ece1 [89].

Although most of the transcription factors above are necessary for hyphal growth at least under some conditions, their ectopic expression is not sufficient to induce authentic hyphal morphogenesis or the full hyphal gene expression profile. One exception is Ume6, high artificial expression of which 
can induce hyphae whilst intermediate expression causes pseudohyphal chain formation [85,90]. Conversely, ume $6^{-/}$mutants, while capable of initiating germ tube formation when transferred to hyphal-inducing conditions, are profoundly defective in hyphal extension under most tested conditions $[84,85]$. The UME6 gene is regulated by many of the transcription factors required for hyphal morphogenesis, including Cph1, Tec1, Flo8, Rfg1 and Nrg1 [84,85].

The environmental inputs that activate the hyphal growth pathways are varied, as mentioned above, and can activate distinct signal transduction pathways. Among the best characterized are the signal transduction pathways that involve the ammonium permease Mep2 [91] and the G-coupled receptor Gpr1 [92]. On the one hand, via Ras (in part at least), these activate both the AMP cyclase Cyr1/Cdc35 and the protein kinase A pathway, thus activating the transcription factor Efg1 [86,93], and, on the other hand, they activate Cph1 via the MAP kinase pathway [94,95]. The temperature signal was shown to depend on the chaperone Hsp90 and the transcription factor Hms1, as well as the CDK Pho85 with its cyclin Pcl1 [77,96]. The Efg1 and Cph1 transcription factors activate various genes, but a central target is the transcription factor gene UME6 $[85,90]$. Ume6 functions in a large measure via the induction of a hyphal-specific cyclin gene, HGC1 [97]. Hgc1, a cyclin of the cell-cycle CDK Cdc28 that is essential for hyphal morphogenesis, is a homolog of the S. cerevisiae G1 cyclins Cln1 and Cln2 [29]. $\mathrm{Hgc1}$ in conjunction with Cdc28 phosphorylates several effectors of morphogenesis, including the Cdc42 GAP Rga2, a central regulator of polar growth [98]; the GEF Sec2, a regulator of polarized secretion at the tip of the hyphae [99]; the exocyst component Exo84 [100]; the septin Cdc11 [101]; and the Spa2 polarisome scaffold protein, maintaining it at the hyphal tip [102]. A simplified hyphal induction pathway, activated by a single stimulus—low nitrogen —is depicted in Figure 1.

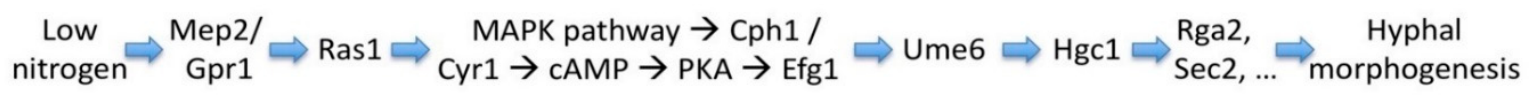

Figure 1. A simplified outline of one C. albicans hyphal morphogenesis signaling pathway.

The pathway shown in Figure 1 is linear, leading from nitrogen starvation via cellular signal transduction pathways to the activation of transcription factors, which in turn leads to the expression of direct effectors of hyphal morphogenesis. This scheme is highly simplified: for example, the Mep2 receptor is involved in nitrogen starvation sensing [91], while other stimuli such as alkaline $\mathrm{pH}$ or GlcNAc, activate other receptors [103,104]; HGC1 is transcribed by Ume6 during hyphal extension, but initial activation relies on other TFs [97]. More comprehensive descriptions of the various pathways involved in hyphal induction under different conditions and by alternative stimuli can be found in recent reviews [22,105]. In common with the scheme in Figure 1, these parallel pathways (examples of which are shown in red in Figure 2 below) all involve linear transduction of signals from the environment via gene expression regulation to the activation of hyphal effector proteins. These signals also include quorum sensing factors [106], of which the best studied is farnesol [107], a molecule that inhibits hyphal morphogenesis by affecting many hyphal-inducing pathways via the direct inactivation of Cyr1 [108], via the indirect stabilization of the transcriptional repressor Nrg1 [109], and via an unknown mechanism involving the Eed1 protein [110]. Thus, the individual fungal cell integrates the inputs of many external stimuli in order to determine whether to initiate hyphal morphogenesis. However additional internal cellular signals also feed into the hypha-specific gene (HSG) expression mechanism. These are discussed below.

While many genes were shown to be involved in hyphal development under several or under specific conditions, only some of these can induce hyphal development in the absence of external stimuli when ectopically expressed. These include the genes for Ras $1^{\mathrm{G} 13 \mathrm{~V}}[56,111,112]$, Ste11 $\Delta \mathrm{N}$ [113], Ume6 [90] and Hgc1 [113], which can all induce the switch from yeast to hyphae and hyphal-specific gene expression under yeast growth conditions, particularly when expressed in the activated form.

A large number of genes are typically induced following the stimulation of hyphal growth from a yeast culture (the hypha-specific genes (HSG)) [69,70]. However, only a few of these genes are actually essential for hyphal morphogenesis. Chief among them are the UME6 and HGC1 genes, 
described above. Conversely, according to one report at least, it appears that under some circumstances, hyphal morphogenesis can be induced without any detectable induction of HSGs [114]. Furthermore, some HSGs such as RBT5 can also be expressed in yeast-form cells under certain conditions such as iron starvation $[115,116]$. Thus, it was suggested that the hypha-specific genes (HSGs) might be more correctly referred to as hypha-associated genes (HAGs) [105]. Nonetheless, we will retain the customary nomenclature here and call these genes HSGs.

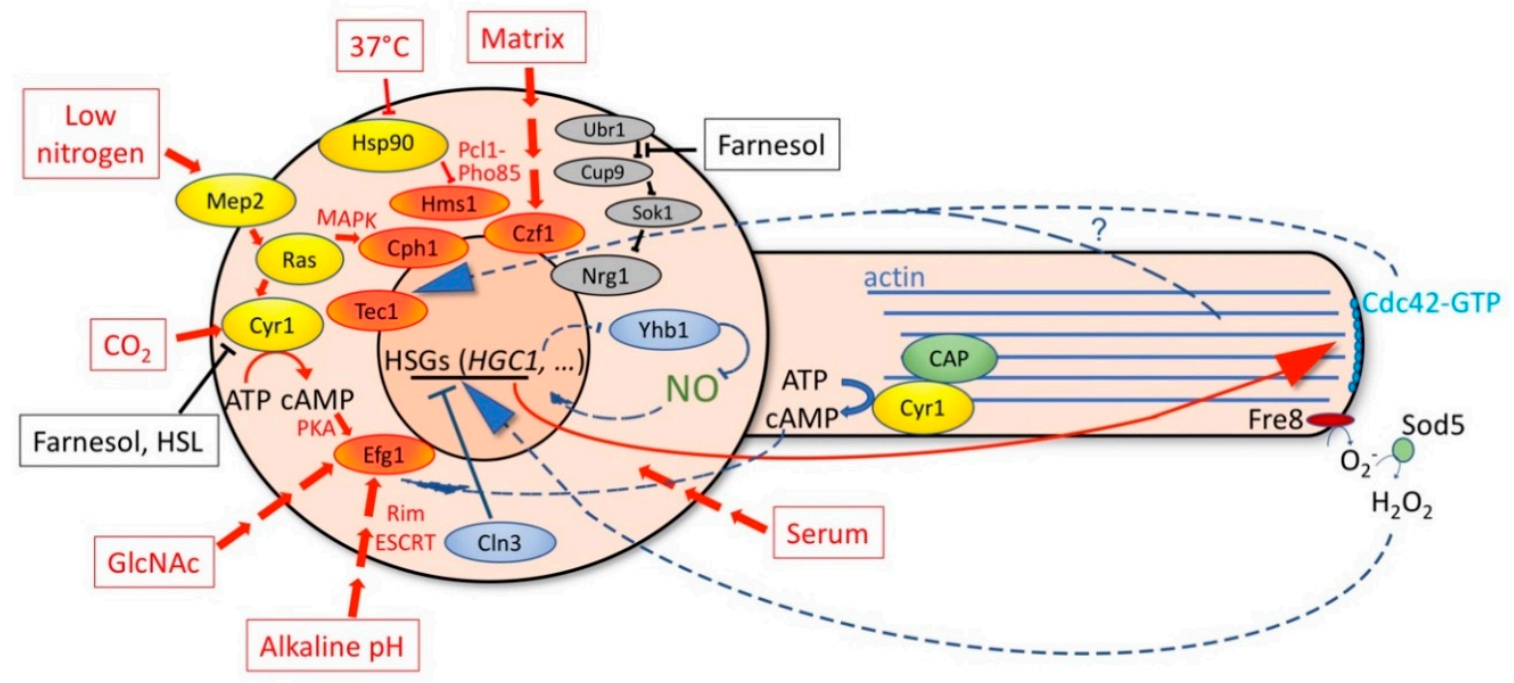

Figure 2. Schematic depiction of some of the positive stimuli on hyphal induction (boxed in red and red arrows) and inhibitory signals (black). The cellular mediators of the hyphal morphogenetic pathways are depicted in yellow ovals and the transcription activators that induce hyphal growth are in orange ovals. The internal signals feeding back from the morphogenetic apparatus (dashed lines) and the cell cycle apparatus (solid lines) to the hypha-specific gene (HSG) expression program are shown in blue. See text for details of the individual interactions. The question mark indicates that it is still unclear whether Cdc42 affects the HSG expression directly or indirectly via its effect on the cytoskeleton.

\section{Regulation of Hyphal Morphogenesis and HSG Expression by Internal Signals}

\subsection{Interference with Yeast Proliferation Induces Hyphal Morphogenesis and HSG Expression}

The established role of the $S$. cerevisiae cell-cycle CDK in the coordination of cell cycle progression with bud morphogenesis [43], as well as its role in S. cerevisiae pseudohyphal growth [117,118], led to the exploration of the role of cell cycle regulators in C. albicans morphogenesis [119]. Interference with cell cycle progression in the absence of external stimuli was found to induce hyphal-like growth; this hyphal morphogenesis is often accompanied by an induction of HSG expression. The types of cell cycle interferences that induce hyphal growth and HSG expression include mitotic inhibition by the depletion of the essential mitotic polo kinase Cdc5 [120,121], S-phase inhibition by the addition of the DNA synthesis inhibitor hydroxyurea, or through the depletion of the ribonucleotide reductase Rnr1, other genotoxic stresses [121,122], or cell cycle arrest in G1 through the depletion of the essential G1 cyclin $C \ln 3[123,124]$. Interference with the activity of the SCF ubiquitin ligase complex, which in S. cerevisiae is essential for the G1-to-S transition [125], by mutating its essential cullin component Cdc53 or by interfering with its Rub1 modification, also induced a filamentous morphology, albeit pseudohyphal rather than hyphal in most cases [126,127]. In contrast, the deletion of CDC4, which encodes one of the alternative substrate recognition components of the SCF complex, led to a strong constitutive hyphal phenotype with aerial hyphae protruding from colonies [128]. The constitutive hyphal phenotype of the $c d c 4^{-/-}$mutant is a consequence of the combined stabilization of two SCFCDC4 substrates, the CDK inhibitor Sol1, which delays cell cycle progression at the G1-to-S transition, and the TF Ume6, which promotes hyphal extension [129]. 
Diminished expression of the essential cell cycle kinases Cak1, an activator of the cell cycle CDK Cdk1/Cdc28, or of Kin28, involved in RNA polymerase II activity, also causes filamentous growth and HSG expression, and so do the reduced activity of mutants in a number of additional essential genes, a phenomenon that has been called "essential process impairment-induced filamentation" [130,131]. Conversely, the acceleration of the cell cycle either by deletion of the cell cycle inhibitor Nrm1 [132] or by the overexpression of $C \ln 3$ [129] inhibits hyphal morphogenesis and HSG expression. The pathways for hyphal induction upon interference with the cell cycle progression include the transcription factor Ume6 and the Cdc28 cyclin Hgc1 in the case of the depletion of Cdc5 or Cln3, but not for hydroxyurea-induced filamentous growth. The latter, however, still required the Ras-cAMP pathway activity $[133,134]$. HSG expression induced by diminished CAK1 expression was surprisingly resistant to the deletion of TFs that are normally essential for hyphal growth under many conditions, in particular, Ume6 and Brg1. Deletion of both UME6 and BRG1 together did, nonetheless, greatly reduce HSG expression in the diminished CAK1 expression background, suggesting that several parallel HSG expression pathways are induced in this background [130]. The signals that induce hyphal morphogenesis upon cell cycle inhibition or essential process impairment, in general, are yet unknown.

\subsection{Actin Depolymerization Blocks Hyphal Morphogenesis and Inhibits HSG Expression}

The linear pathway shown in Figure 1 would suggest that after induction of hyphal morphogenesis by external stimuli, interference with the actin cytoskeleton using actin depolymerizing drugs such as cytochalasin A and latrunculin A should inhibit cellular morphogenesis, but not HSG expression. This is, however, not what was observed. These two drugs inhibited hyphal morphogenesis, but also caused a strong suppression of HSG expression [58,135]. Similar suppression was noted with mutants that are defective in actin nucleation but, conversely, the drug jasplakinolide that inhibits hyphal elongation by stabilizing filamentous actin was not defective in HSG expression [135]. These observations suggest the existence of a mechanism linking the filamentous actin cytoskeleton, possibly via cAMP levels [135], to the regulation of HSG expression. This mechanism may involve the adenylyl cyclase Cyr1, which is essential for the hyphal morphogenesis gene expression program and which, via the Cap1 protein, binds to actin [136]. However, the details of this mechanism are unknown.

\subsection{Inhibition of Endocytosis Inhibits Hyphal Morphogenesis and HSG Expression}

As mentioned in Section 2, hyphal morphogenesis requires that exocytosis be balanced by endocytosis, and indeed, a collar of endocytic actin patches is located sub-apically in growing hyphae. Thus, not surprisingly, when general endocytosis is inhibited either pharmacologically [113] using Trifluoperazine or related compounds, or genetically through the deletion of the BAR proteins Rvs161 or Rvs167 [137], or by overexpressing the inhibitory Akl1 kinase [138], hyphal extension is inhibited. However, in addition, HSG expression is also strongly inhibited under these conditions [113,138]. Furthermore, the activation of endocytosis through deletion of the inhibitory kinase Akl1 or through the overexpression of the endocytic scaffold protein Pan1 both increased the rate of hyphal elongation and the expression of HSGs [138]. Since there is no known connection between the endocytic proteins Akl1 and Pan1 and the signal transduction pathways of hyphal induction, it appears that interference with the mechanism of hyphal extension can indirectly affect the HSG expression.

\section{Feedback Regulations in Hyphal Morphogenesis}

\subsection{Positive Feedback Regulations of Hyphal Transcription}

To achieve sustained hyphal extension may require positive feedback (or "feed-forward") regulations in order to ensure the continuation of the HSG expression program beyond its initial activation. One instance of a feed-forward regulation is that of the transcription factor Ume6, whose gene is activated under hyphal induction conditions. Ume6 was shown to activate its own gene's promoter under hyphal induction conditions and this reinforcing feedback loop was essential for the 
maintenance of hyphal elongation [139]. Another mechanism that could contribute to the persistence of the HSG expression program relies on chromatin modifiers that perpetuate an active chromatin state by histone deacetylation. The initiation of HSG expression induces the down-regulation of the expression of a transcriptional repressor, $\mathrm{Nrg} 1$ [140], as well as the degradation of the Nrg1 protein [109], causing inter alia the activation of the TF gene BRG1 [87]. Brg1 then recruits the deacetylase Hda1 to HSG promoters, which causes histone deacetylation indirectly through the inactivation of the NuA4 histone acetyltransferase complex $[87,141]$. Upon Nrg1 removal, Brg1 can itself also activate its own promoter in another feed-forward loop that can perpetuate the expression of HSGs [141].

\section{2. $C d c 42$}

The small GTPase Cdc42 is an essential protein for yeast growth and proliferation and it is also specifically involved in hyphal elongation. Misregulation of Cdc42 activity or localization either through mutation, by increasing or decreasing its expression, or by manipulating its associated GTP exchange factor (Cdc24) or its associated proteins Bem1 and Rsr1, causes a disruption in hyphal morphogenesis $[58,59,61,63,142,143]$. Interestingly, in the absence of proper hyphal morphogenetic Cdc42 activity, including properly focused localization at the hyphal tip, the initial HSG expression cannot be sustained $[61,63,143]$. This could be due to the role of the Cdc42 activity in actin cytoskeleton polarization which, in turn, can affect the HSG expression program, as discussed above. On the other hand, the toxicity of the activated $C D C 42^{\mathrm{G} 12 \mathrm{~V}}$ allele could be suppressed by the deletion of the MAP kinase signaling pathway protein Cst20, suggesting that in addition to its cytoskeletal role in hyphal morphogenesis, Cdc42 might be directly involved in the transduction of the hyphal induction signals via the MAPK pathway [59]. Nonetheless, additional observations indicate that Cdc42 plays a role in maintenance, rather than in the initial induction, of the HSG expression during hyphal morphogenesis [61]. Furthermore, the focused localization of the Cdc42 protein at the hyphal apex is necessary for its effect on HSG expression [63]. Thus, whereas a direct role for Cdc42 in the MAPK signal transduction pathway cannot be excluded, it is likely that the Cdc42 morphogenetic complex impacts HSG expression indirectly via its effect on hyphal morphogenesis.

\subsection{Reactive Oxygen and Nitrogen Species}

Nitric oxide (NO) and reactive oxygen species (ROS) such as the superoxide radical and hydrogen peroxide are toxic compounds generated by host phagocytic cells in response to invading microorganisms. Conversely, the microorganisms have evolved mechanisms to detoxify these reactive species (recently reviewed in Reference [144]). In addition, exogenous $\mathrm{H}_{2} \mathrm{O}_{2}$ was shown to promote, at sub-toxic levels, polarized cellular growth [145]. Interestingly, however, a recent report indicates that the $C$. albicans hyphal cells can themselves generate $\mathrm{H}_{2} \mathrm{O}_{2}$ via disproportionation through the superoxide dismutase Sod5 of the superoxide ion generated by the NADPH oxidase Fre8 at the hyphal tip, and that this $\mathrm{H}_{2} \mathrm{O}_{2}$ contributes to hyphal morphogenesis [146]. FRE8 is itself strongly induced under hyphal growth conditions, potentially providing a reinforcing loop that sustains morphogenesis using this "autocrine" mechanism.

In another recent study, endogenous NO was found to be associated with hyphal morphogenesis: the pharmacological inhibition of NO generation prevented hyphal morphogenesis via the prevention of the normal degradation of the HSG suppressor Nrg1 under hyphal induction conditions [147]. Consistent with the notion that elevated NO promotes hyphal morphogenesis, the deletion of the main NO detoxifying enzyme, Yhb1, caused hyper-filamentation [148]. YHB1 expression is suppressed under hyphal induction conditions [149], providing another potential reinforcing feedback regulation on hyphal morphogenesis.

\section{Conclusions}

The hyphal development program, once initiated, likely requires commitment mechanisms in order to be sustained. Commitment could be achieved by positive feedback regulatory loops such 
as the transcriptional feed-forward loops, the effects of actin cytoskeleton polarization on the HSG expression program, and the ROS- and NO-mediated regulation of hyphal morphogenesis described above. The internal signals that can affect hyphal gene expression are schematically indicated in Figure 2 with blue arrows.

Besides the external hyphae-inducing stimuli that are transmitted via well-studied transduction pathways to the nucleus to induce the HSG expression program and hyphal growth (red arrows in Figure 2), a significant number of cellular conditions have been identified that can also induce hyphal morphogenesis. These include mutations or treatments that inhibit cell cycle progression or otherwise inhibit essential cellular processes. Given that the abilities to form hyphae and to generate biofilms are correlated, it was suggested that hyphal induction upon the inhibition of proliferation represents an evolved cellular response, which maximizes cell attachment and substrate penetration upon encountering adverse conditions, thereby enabling, e.g., biofilm formation as a coping mechanism [131]. This possibility implies the existence of sensors of cellular growth capacity that transmit information on the internal state of the cell to the HSG expression system. One candidate for such a sensor is the essential G1 cyclin Cln3: high levels of Cln3 promote yeast proliferation and inhibit hyphal morphogenesis $[129,138]$, whereas reduced Cln3 levels promote hyphal morphogenesis $[123,124,130]$. It is not known how $C$. albicans $C \ln 3$ levels are regulated, but one possibility is that by analogy with S. cerevisiae, where $C \ln 3$ protein levels are strongly associated with cell proliferation rates [150], the $C$. albicans $C \ln 3$ cyclin likewise serves as a sensor of the cellular biosynthetic capacity.

It is, however, also possible that rather than being an evolved function, the cell cycle inhibitionmediated hyphae formation is a consequence of mechanisms that normally ensure commitment to hyphal morphogenesis. For example, cell cycle inhibition could induce an initial cytoskeletal polarization due to, e.g., an imbalance between the actions of the different Cdc28 cyclins. This initial polarization could then be further amplified to the extent that cytoskeletal polarization can affect the HSG expression, leading to hyphal morphogenesis in the absence of regular stimuli. The cell cycle inhibition-induced mode of hyphal morphogenesis could thus represent a spurious consequence of the existence of the positively reinforcing cellular mechanisms that ensure commitment to morphogenesis after germ tube initiation.

The possibilities that cell cycle inhibition-induced hyphal morphogenesis represents an evolved response or that it is a consequence of reinforcing feedback loops in the morphogenetic pathway that are activated under certain artificial conditions are not mutually exclusive. In either case, future challenges will include the elucidation of the molecular mechanisms that connect the hyphal extension apparatus to the HSG expression program. Cell cycle inhibition-induced hyphal morphogenesis, regardless of its evolutionary basis, provides a useful experimental window into the mechanisms that sustain hyphal growth.

Acknowledgments: Research in the author's laboratory is funded by the Israel Science Foundation and by the U.S.-Israel Binational Science Foundation.

Conflicts of Interest: The author declares no conflict of interest.

\section{References}

1. Nash, A.K.; Auchtung, T.A.; Wong, M.C.; Smith, D.P.; Gesell, J.R.; Ross, M.C.; Stewart, C.J.; Metcalf, G.A.; Muzny, D.M.; Gibbs, R.A.; et al. The gut mycobiome of the Human Microbiome Project healthy cohort. Microbiome 2017, 5, 153. [CrossRef] [PubMed]

2. Ghannoum, M.A.; Jurevic, R.J.; Mukherjee, P.K.; Cui, F.; Sikaroodi, M.; Naqvi, A.; Gillevet, P.M. Characterization of the Oral Fungal Microbiome (Mycobiome) in Healthy Individuals. PLoS Pathog. 2010, 6, e1000713. [CrossRef] [PubMed]

3. Kam, A.P.; Xu, J. Diversity of commensal yeasts within and among healthy hosts. Diagn. Microbiol. Infect. Dis. 2002, 43, 19-28. [CrossRef]

4. Calderone, R.A.; Clancy, C.J. Candida and Candidiasis, 2nd ed.; Calderone, R.A., Clancy, C.J., Eds.; ASM Press: Washington, DC, USA, 2012; ISBN 9781555815394. 
5. Pfaller, M.A.; Diekema, D.J. Epidemiology of invasive candidiasis: A persistent public health problem. Clin. Microbiol. Rev. 2007, 20, 133-163. [CrossRef] [PubMed]

6. Pfaller, M.A.; Diekema, D.J. Epidemiology of invasive mycoses in North America. Crit. Rev. Microbiol. 2010, 36, 1-53. [CrossRef] [PubMed]

7. Falagas, M.E.; Roussos, N.; Vardakas, K.Z. Relative frequency of albicans and the various non-albicans Candida spp among candidemia isolates from inpatients in various parts of the world: A systematic review. Int. J. Infect. Dis. 2010, 14, e954-e966. [CrossRef] [PubMed]

8. Pfaller, M.; Neofytos, D.; Diekema, D.; Azie, N.; Meier-Kriesche, H.U.; Quan, S.P.; Horn, D. Epidemiology and outcomes of candidemia in 3648 patients: Data from the Prospective Antifungal Therapy (PATH Alliance(R)) registry, 2004-2008. Diagn. Microbiol. Infect. Dis. 2012, 74, 323-331. [CrossRef] [PubMed]

9. Kullberg, B.J.; Arendrup, M.C. Invasive Candidiasis. N. Engl. J. Med. 2015, 373, 1445-1456. [CrossRef] [PubMed]

10. Gudlaugsson, O.; Gillespie, S.; Lee, K.; Vande Berg, J.; Hu, J.; Messer, S.; Herwaldt, L.; Pfaller, M.; Diekema, D. Attributable mortality of nosocomial candidemia, revisited. Clin. Infect. Dis. 2003, 37, 1172-1177. [CrossRef] [PubMed]

11. Hassan, I.; Powell, G.; Sidhu, M.; Hart, W.M.; Denning, D.W. Excess mortality, length of stay and cost attributable to Candidaemia. J. Infect. 2009, 59, 360-365. [CrossRef] [PubMed]

12. Mora-Duarte, J.; Betts, R.; Rotstein, C.; Colombo, A.L.; Thompson-Moya, L.; Smietana, J.; Lupinacci, R.; Sable, C.; Kartsonis, N.; Perfect, J. Comparison of caspofungin and amphotericin B for invasive candidiasis. N. Engl. J. Med. 2002, 347, 2020-2029. [CrossRef] [PubMed]

13. Cuervo, G.; Garcia-Vidal, C.; Nucci, M.; Puchades, F.; Fernández-Ruiz, M.; Obed, M.; Manzur, A.; Gudiol, C.; Pemán, J.; Aguado, J.M.; et al. Breakthrough Candidaemia in the era of broad-spectrum antifungal therapies. Clin. Microbiol. Infect. 2016, 22, 181-188. [CrossRef] [PubMed]

14. Pappas, P.G.; Kauffman, C.A.; Andes, D.R.; Clancy, C.J.; Marr, K.A.; Ostrosky-Zeichner, L.; Reboli, A.C.; Schuster, M.G.; Vazquez, J.A.; Walsh, T.J.; et al. Clinical Practice Guideline for the Management of Candidiasis: 2016 Update by the Infectious Diseases Society of America. Clin. Infect. Dis. 2015, 62, civ933. [CrossRef] [PubMed]

15. Bongomin, F.; Gago, S.; Oladele, R.; Denning, D. Global and Multi-National Prevalence of Fungal Diseases-Estimate Precision. J. Fungi 2017, 3, 57. [CrossRef] [PubMed]

16. Sudbery, P.; Gow, N.; Berman, J. The distinct morphogenic states of Candida albicans. Trends Microbiol. 2004, 12,317-324. [CrossRef] [PubMed]

17. Sharma, J.; Rosiana, S.; Razzaq, I.; Shapiro, R. Linking Cellular Morphogenesis with Antifungal Treatment and Susceptibility in Candida Pathogens. J. Fungi 2019, 5, 17. [CrossRef] [PubMed]

18. Stokes, C.; Moran, G.P.; Spiering, M.J.; Cole, G.T.; Coleman, D.C.; Sullivan, D.J. Lower filamentation rates of Candida dubliniensis contribute to its lower virulence in comparison with Candida albicans. Fungal Genet. Biol. 2007, 44, 920-931. [CrossRef] [PubMed]

19. Lackey, E.; Vipulanandan, G.; Childers, D.S.; Kadosh, D. Comparative Evolution of Morphological Regulatory Functions in Candida Species. Eukaryot. Cell 2013, 12, 1356-1368. [CrossRef] [PubMed]

20. Yue, H.; Bing, J.; Zheng, Q.; Zhang, Y.; Hu, T.; Du, H.; Wang, H.; Huang, G. Filamentation in Candida auris, an emerging fungal pathogen of humans: Passage through the mammalian body induces a heritable phenotypic switch. Emerg. Microbes Infect. 2018, 7, 188. [CrossRef] [PubMed]

21. Hall, R.A.; Cottier, F.; Muhlschlegel, F.A. Molecular networks in the fungal pathogen Candida albicans. Adv. Appl. Microbiol. 2009, 67, 191-212. [CrossRef] [PubMed]

22. Sudbery, P.E. Growth of Candida albicans hyphae. Nat. Rev. Microbiol. 2011, 9, 737-748. [CrossRef] [PubMed]

23. Richardson, M.D.; Warnock, D.W. Fungal Infection-Diagnosis and Management, 2nd ed.; Blackwell Sciences Ltd.: Oxford, UK, 1997.

24. Koh, A.Y.; Kohler, J.R.; Coggshall, K.T.; Van Rooijen, N.; Pier, G.B. Mucosal damage and neutropenia are required for Candida albicans dissemination. PLoS Pathog. 2008, 4, e35. [CrossRef] [PubMed]

25. Marcil, A.; Harcus, D.; Thomas, D.Y.; Whiteway, M. Candida albicans killing by RAW 264.7 mouse macrophage cells: Effects of Candida genotype, infection ratios, and gamma interferon treatment. Infect. Immun. Infect. Immun. 2002, 70, 6319-6329. [CrossRef]

26. Ghosh, S.; Navarathna, D.H.M.L.P.; Roberts, D.D.; Cooper, J.T.; Atkin, A.L.; Petro, T.M.; Nickerson, K.W. Arginine-Induced germ tube formation in Candida albicans is essential for escape from murine macrophage line RAW 264.7. Infect. Immun. 2009, 77, 1596-1605. [CrossRef] [PubMed] 
27. McKenzie, C.G.; Koser, U.; Lewis, L.E.; Bain, J.M.; Mora-Montes, H.M.; Barker, R.N.; Gow, N.A.; Erwig, L.P. Contribution of Candida albicans cell wall components to recognition by and escape from murine macrophages. Infect. Immun. 2010, 78, 1650-1658. [CrossRef] [PubMed]

28. Nobile, C.J.; Johnson, A.D. Candida albicans Biofilms and Human Disease. Annu. Rev. Microbiol. 2015, 69, 71-92. [CrossRef] [PubMed]

29. Zheng, X.; Wang, Y. Hgc1, a novel hypha-specific G1 cyclin-related protein regulates Candida albicans hyphal morphogenesis. EMBO J. 2004, 23, 1845-1856. [CrossRef] [PubMed]

30. Lo, H.-J.; Kohler, J.; DiDomenico, B.; Loebenberg, D.; Cacciapuoti, A.; Fink, G.R. Nonfilamentous C. albicans mutants are avirulent. Cell 1997, 90, 939-950. [CrossRef]

31. Saville, S.P.; Lazzell, A.L.; Monteagudo, C.; Lopez-Ribot, J.L. Engineered control of cell morphology in vivo reveals distinct roles for yeast and filamentous forms of Candida albicans during infection. Eukaryot. Cell 2003, 2, 1053-1060. [CrossRef] [PubMed]

32. Saville, S.P.; Lazzell, A.L.; Bryant, A.P.; Fretzen, A.; Monreal, A.; Solberg, E.O.; Monteagudo, C.; Lopez-Ribot, J.L.; Milne, G.T. Inhibition of filamentation can be used to treat disseminated candidiasis. Antimicrob. Agents Chemother. 2006, 50, 3312-3316. [CrossRef] [PubMed]

33. Noble, S.M.; French, S.; Kohn, L.A.; Chen, V.; Johnson, A.D. Systematic screens of a Candida albicans homozygous deletion library decouple morphogenetic switching and pathogenicity. Nat. Genet. 2010, 42, 590-598. [CrossRef] [PubMed]

34. O'Meara, T.R.; Veri, A.O.; Ketela, T.; Jiang, B.; Roemer, T.; Cowen, L.E. Global analysis of fungal morphology exposes mechanisms of host cell escape. Nat. Commun. 2015, 6, 6741. [CrossRef] [PubMed]

35. Jacobsen, I.D.; Wilson, D.; Wachtler, B.; Brunke, S.; Naglik, J.R.; Hube, B. Candida albicans dimorphism as a therapeutic target. Expert Rev. Anti-Infect. Ther. 2012, 10, 85-93. [CrossRef] [PubMed]

36. Vila, T.; Romo, J.A.; Pierce, C.G.; McHardy, S.F.; Saville, S.P.; Lopez-Ribot, J.L. Targeting Candida albicans filamentation for antifungal drug development. Virulence 2017, 8, 150-158. [CrossRef] [PubMed]

37. Ruhnke, M. Skin and mucous membrane infections. In Candida and candidiasis; Calderone, R.A., Ed.; ASM Press: Washington, DC, USA, 2002; pp. 307-325.

38. Blostein, F.; Levin-Sparenberg, E.; Wagner, J.; Foxman, B. Recurrent vulvovaginal candidiasis. Ann. Epidemiol. 2017, 27, 575-582.e3. [CrossRef] [PubMed]

39. Sobel, J.D.; Muller, G.; Buckley, H.R. Critical role of germ tube formation in the pathogenesis of Candidal vaginitis. Infect. Immun. 1984, 44, 576-580. [PubMed]

40. Martin, M.V.; Craig, G.T.; Lamb, D.J. An investigation of the role of true hypha production in the pathogenesis of experimental oral candidosis. Sabouraudia 1984, 22, 471-476. [CrossRef] [PubMed]

41. Hisajima, T.; Ishibashi, H.; Yamada, T.; Nishiyama, Y.; Yamaguchi, H.; Funakoshi, K.; Abe, S. Invasion process of Candida albicans to tongue surface in early stages of experimental murine oral candidiasis. Med. Mycol. 2008, 46, 697-704. [CrossRef] [PubMed]

42. Peters, B.M.; Palmer, G.E.; Nash, A.K.; Lilly, E.A.; Fidel, P.L., Jr.; Noverr, M.C. Fungal morphogenetic pathways are required for the hallmark inflammatory response during Candida albicans vaginitis. Infect. Immun. 2014, 82, 532-543. [CrossRef] [PubMed]

43. Lew, D.J.; Reed, S.I. Morphogenesis in the yeast cell cycle: Regulation by Cdc28 and cyclins. J. Cell Biol. 1993, 120, 1305-1320. [CrossRef] [PubMed]

44. Chiou, J.; Balasubramanian, M.K.; Lew, D.J. Cell Polarity in Yeast. Annu. Rev. Cell Dev. Biol. 2017, 33, 77-101. [CrossRef] [PubMed]

45. Liu, H. Transcriptional control of dimorphism in Candida albicans. Curr. Opin. Microbiol. 2001, 4, $728-735$. [CrossRef]

46. Steinberg, G.; Peñalva, M.A.; Riquelme, M.; Wösten, H.A.; Harris, S.D. Cell Biology of Hyphal Growth. Microbiol. Spectr. 2017, 5, 1-34. [CrossRef]

47. Riquelme, M.; Aguirre, J.; Bartnicki-García, S.; Braus, G.H.; Feldbrügge, M.; Fleig, U.; Hansberg, W.; Herrera-Estrella, A.; Kämper, J.; Kück, U.; et al. Fungal Morphogenesis, from the Polarized Growth of Hyphae to Complex Reproduction and Infection Structures. Microbiol. Mol. Biol. Rev. 2018, 82, e00068-17. [CrossRef] [PubMed]

48. Bartnicki-Garcia, S.; Garduño-Rosales, M.; Delgado-Alvarez, D.L.; Mouriño-Pérez, R.R. Experimental measurement of endocytosis in fungal hyphae. Fungal Genet. Biol. 2018, 118, 32-36. [CrossRef] [PubMed] 
49. Hernández-González, M.; Bravo-Plaza, I.; Pinar, M.; de Los Ríos, V.; Arst, H.N.; Peñalva, M.A. Endocytic recycling via the TGN underlies the polarized hyphal mode of life. PLoS Genet. 2018, 14, e1007291. [CrossRef] [PubMed]

50. Araujo-Bazán, L.; Peñalva, M.A.; Espeso, E.A. Preferential localization of the endocytic internalization machinery to hyphal tips underlies polarization of the actin cytoskeleton in Aspergillus nidulans. Mol. Microbiol. 2008, 67, 891-905. [CrossRef] [PubMed]

51. Yokoyama, K.; Kaji, H.; Nishimura, K.; Miyaji, M. The role of microfilaments and microtubules in apical growth and dimorphism of Candida albicans. J. Gen. Microbiol. 1990, 136, 1067-1075. [CrossRef] [PubMed]

52. Rida, P.C.G.; Nishikawa, A.; Won, G.Y.; Dean, N. Yeast-to-Hyphal Transition Triggers Formin-dependent Golgi Localization to the Growing Tip in Candida albicans. Mol. Biol. Cell 2006, 17, 4364-4378. [CrossRef] [PubMed]

53. Crampin, H.; Finley, K.; Gerami-Nejad, M.; Court, H.; Gale, C.; Berman, J.; Sudbery, P. Candida albicans hyphae have a Spitzenkörper that is distinct from the polarisome found in yeast and pseudohyphae. J. Cell Sci. 2005, 118, 2935-2947. [CrossRef] [PubMed]

54. Weiner, A.; Orange, F.; Lacas-Gervais, S.; Rechav, K.; Ghugtyal, V.; Bassilana, M.; Arkowitz, R.A. On-site secretory vesicle delivery drives filamentous growth in the fungal pathogen Candida albicans. Cell. Microbiol. 2018, e12963. [CrossRef] [PubMed]

55. Jones, L.A.; Sudbery, P.E. Spitzenkörper, exocyst, and polarisome components in Candida albicans hyphae show different patterns of localization and have distinct dynamic properties. Eukaryot. Cell 2010, 9, 1455-1465. [CrossRef] [PubMed]

56. Martin, R.; Walther, A.; Wendland, J. Ras1-induced hyphal development in Candida albicans requires the formin Bni1. Eukaryot. Cell 2005, 4, 1712-1724. [CrossRef] [PubMed]

57. Li, C.R.; Wang, Y.M.; De Zheng, X.; Liang, H.Y.; Tang, J.C.W.; Wang, Y. The formin family protein CaBni1p has a role in cell polarity control during both yeast and hyphal growth in Candida albicans. J. Cell Sci. 2005, 118, 2637-2648. [CrossRef] [PubMed]

58. Hazan, I.; Liu, H. Hyphal tip-associated localization of Cdc42 is F-actin dependent in Candida albicans. Eukaryot Cell 2002, 1, 856-864. [CrossRef] [PubMed]

59. Ushinsky, S.C.; Harcus, D.; Ash, J.; Dignard, D.; Marcil, A.; Morchhauser, J.; Thomas, D.Y.; Whiteway, M.; Leberer, E. CDC42 is required for polarized growth in human pathogen Candida albicans. Eukaryot. Cell 2002, 1, 95-104. [CrossRef] [PubMed]

60. Arkowitz, R.A.; Bassilana, M. Regulation of hyphal morphogenesis by Ras and Rho small GTPases. Fungal Biol. Rev. 2015, 29,7-19. [CrossRef]

61. Bassilana, M.; Hopkins, J.; Arkowitz, R.A. Regulation of the Cdc42/Cdc24 GTPase module during Candida albicans hyphal growth. Eukaryot Cell 2005, 4, 588-603. [CrossRef] [PubMed]

62. Court, H.; Sudbery, P. Regulation of Cdc42 GTPase Activity in the Formation of Hyphae in Candida albicans. Mol. Biol. Cell 2007, 18, 265-281. [CrossRef] [PubMed]

63. Pulver, R.; Heisel, T.; Gonia, S.; Robins, R.; Norton, J.; Haynes, P.; Gale, C.A. Rsr1 focuses CDC42 activity at hyphal tips and promotes maintenance of hyphal development in Candida albicans. Eukaryot. Cell 2013, 12, 482-495. [CrossRef] [PubMed]

64. Brand, A.; Vacharaksa, A.; Bendel, C.; Norton, J.; Haynes, P.; Henry-Stanley, M.; Wells, C.; Ross, K.; Gow, N.A.R.; Gale, C.A. An internal polarity landmark is important for externally induced hyphal behaviors in Candida albicans. Eukaryot. Cell 2008, 7, 712-720. [CrossRef] [PubMed]

65. Thomson, D.D.; Wehmeier, S.; Byfield, F.J.; Janmey, P.A.; Caballero-Lima, D.; Crossley, A.; Brand, A.C. Contact-induced apical asymmetry drives the thigmotropic responses of Candida albicans hyphae. Cell. Microbiol. 2015, 17, 342-354. [CrossRef] [PubMed]

66. Csank, C.; Schroppel, K.; Leberer, E.; Harcus, D.; Mohamed, O.; Meloche, S.; Thomas, D.Y.; Whiteway, M. Roles of the Candida albicans mitogen-activated protein kinase homolog, Cek1p, in hyphal development and systemic candidiasis. Infect. Immun. 1998, 66, 2713-2721. [PubMed]

67. Rocha, C.R.; Schroppel, K.; Harcus, D.; Marcil, A.; Dignard, D.; Taylor, B.N.; Thomas, D.Y.; Whiteway, M.; Leberer, E. Signaling through adenylyl cyclase is essential for hyphal growth and virulence in the pathogenic fungus Candida albicans. Mol. Biol. Cell 2001, 12, 3631-3643. [CrossRef] [PubMed]

68. Cloutier, M.; Castilla, R.; Bolduc, N.; Zelada, A.; Martineau, P.; Bouillon, M.; Magee, B.B.; Passeron, S.; Giasson, L.; Cantore, M.L. The two isoforms of the cAMP-dependent protein kinase catalytic subunit are involved in the control of dimorphism in the human fungal pathogen Candida albicans. Fungal Genet. Biol. 2003, 38, 133-141. [CrossRef] 
69. Nantel, A.; Dignard, D.; Bachewich, C.; Harcus, D.; Marcil, A.; Bouin, A.P.; Sensen, C.W.; Hogues, H.; van het Hoog, M.; Gordon, P.; et al. Transcription profiling of Candida albicans cells undergoing the yeast-to-hyphal transition. Mol. Biol. Cell 2002, 13, 3452-3465. [CrossRef] [PubMed]

70. Kadosh, D.; Johnson, A.D. Induction of the Candida albicans filamentous growth program by relief of transcriptional repression: A genome-wide analysis. Mol. Biol. Cell 2005, 16, 2903-2912. [CrossRef] [PubMed]

71. Liu, H.; Kohler, J.; Fink, G.R. Suppression of hyphal formation in Candida albicans by mutation of a STE12 homolog. Science 1994, 266, 1723-1726. [CrossRef] [PubMed]

72. Stoldt, V.R.; Sonneborn, A.; Leuker, C.E.; Ernst, J.F. Efg1p, an essential regulator of morphogenesis of the human pathogen Candida albicans, is a member of a conserved class of bHLH proteins regulating morphogenetic processes in fungi. EMBO J. 1997, 16, 1982-1991. [CrossRef] [PubMed]

73. Lane, S.; Zhou, S.; Pan, T.; Dai, Q.; Liu, H. The basic helix-loop-helix transcription factor Cph2 regulates hyphal development in Candida albicans partly via TEC1. Mol Cell Biol 2001, 21, 6418-6428. [CrossRef] [PubMed]

74. Brown, D.H., Jr.; Giusani, A.D.; Chen, X.; Kumamoto, C.A. Filamentous growth of Candida albicans in response to physical environmental cues and its regulation by the unique CZF1 gene. Mol. Microbiol. 1999, 34, 651-662. [CrossRef] [PubMed]

75. Schweizer, A.; Rupp, S.; Taylor, B.N.; Rollinghoff, M.; Schroppel, K. The TEA/ATTS transcription factor CaTec1p regulates hyphal development and virulence in Candida albicans. Mol. Microbiol. 2000, 38, 435-445. [CrossRef] [PubMed]

76. Davis, D.; Edwards, J.E., Jr.; Mitchell, A.P.; Ibrahim, A.S. Candida albicans RIM101 pH response pathway is required for host-pathogen interactions. Infect Immun. 2000, 68, 5953-5959. [PubMed]

77. Shapiro, R.S.; Sellam, A.; Tebbji, F.; Whiteway, M.; Nantel, A.; Cowen, L.E. Pho85, Pcl1, and Hms1 Signaling Governs Candida albicans Morphogenesis Induced by High Temperature or Hsp90 Compromise. Curr. Biol. 2012, 22, 461-470. [CrossRef] [PubMed]

78. Braun, B.R.; Johnson, A.D. Control of filament formation in Candida albicans by the transcriptional repressor TUP1. Science 1997, 277, 105-109. [CrossRef] [PubMed]

79. Murad, A.M.; Leng, P.; Straffon, M.; Wishart, J.; Macaskill, S.; MacCallum, D.; Schnell, N.; Talibi, D.; Marechal, D.; Tekaia, F.; et al. NRG1 represses yeast-hypha morphogenesis and hypha-specific gene expression in Candida albicans. EMBO J. 2001, 20, 4742-4752. [CrossRef] [PubMed]

80. Cao, F.; Lane, S.; Raniga, P.P.; Lu, Y.; Zhou, Z.; Ramon, K.; Chen, J.; Liu, H. The Flo8 Transcription Factor Is Essential for Hyphal Development and Virulence in Candida albicans. Mol. Biol. Cell 2006, 17, $295-307$. [CrossRef] [PubMed]

81. Du, H.; Guan, G.; Xie, J.; Sun, Y.; Tong, Y.; Zhang, L.; Huang, G. Roles of Candida albicans Gat2, a GATA-Type Zinc Finger Transcription Factor, in Biofilm Formation, Filamentous Growth and Virulence. PLoS ONE 2012, 7, e29707. [CrossRef] [PubMed]

82. Rottmann, M.; Dieter, S.; Brunner, H.; Rupp, S. A screen in Saccharomyces cerevisiae identified CaMCM1, an essential gene in Candida albicans crucial for morphogenesis. Mol. Microbiol. 2003, 47, 943-959. [CrossRef] [PubMed]

83. Bensen, E.S.; Filler, S.G.; Berman, J. A forkhead transcription factor is important for true hyphal as well as yeast morphogenesis in Candida albicans. Eukaryot. Cell 2002, 1, 787-798. [CrossRef] [PubMed]

84. Banerjee, M.; Thompson, D.S.; Lazzell, A.; Carlisle, P.L.; Pierce, C.; Monteagudo, C.; Lopez-Ribot, J.L.; Kadosh, D. UME6, a novel filament-specific regulator of Candida albicans hyphal extension and virulence. Mol. Biol. Cell 2008, 19, 1354-1365. [CrossRef] [PubMed]

85. Zeidler, U.; Lettner, T.; Lassnig, C.; Muller, M.; Lajko, R.; Hintner, H.; Breitenbach, M.; Bito, A. UME6 is a crucial downstream target of other transcriptional regulators of true hyphal development in Candida albicans. FEMS Yeast Res 2009, 9, 126-142. [CrossRef] [PubMed]

86. Bockmuhl, D.P.; Ernst, J.F. A potential phosphorylation site for an A-type kinase in the Efg1 regulator protein contributes to hyphal morphogenesis of Candida albicans. Genetics 2001, 157, 1523-1530. [PubMed]

87. Lu, Y.; Su, C.; Wang, A.; Liu, H. Hyphal development in Candida albicans requires two temporally linked changes in promoter chromatin for initiation and maintenance. PLoS Biol 2011, 9, e1001105. [CrossRef]

88. Lane, S.; Birse, C.; Zhou, S.; Matson, R.; Liu, H. DNA array studies demonstrate convergent regulation of virulence factors by Cph1, Cph2, and Efg1 in Candida albicans. J. Biol. Chem. 2001, 276, 48988-48996. [CrossRef] [PubMed] 
89. Martin, R.; Albrecht-Eckardt, D.; Brunke, S.; Hube, B.; Hünniger, K.; Kurzai, O. A Core Filamentation Response Network in Candida albicans Is Restricted to Eight Genes. PLoS ONE 2013, 8. [CrossRef] [PubMed]

90. Carlisle, P.L.; Banerjee, M.; Lazzell, A.; Monteagudo, C.; Lopez-Ribot, J.L.; Kadosh, D. Expression levels of a filament-specific transcriptional regulator are sufficient to determine Candida albicans morphology and virulence. Proc. Natl. Acad. Sci. USA 2009, 106, 599-604. [CrossRef] [PubMed]

91. Biswas, K.; Morschhauser, J. The Mep2p ammonium permease controls nitrogen starvation-induced filamentous growth in Candida albicans. Mol. Microbiol. 2005, 56, 649-669. [CrossRef] [PubMed]

92. Maidan, M.M.; De Rop, L.; Serneels, J.; Exler, S.; Rupp, S.; Tournu, H.; Thevelein, J.M.; Van Dijck, P. The G protein-coupled receptor Gpr1 and the Galpha protein Gpa2 act through the cAMP-protein kinase A pathway to induce morphogenesis in Candida albicans. Mol. Biol. Cell 2005, 16, 1971-1986. [CrossRef] [PubMed]

93. Bockmuhl, D.P.; Krishnamurthy, S.; Gerads, M.; Sonneborn, A.; Ernst, J.F. Distinct and redundant roles of the two protein kinase A isoforms Tpk1p and Tpk2p in morphogenesis and growth of Candida albicans. Mol. Microbiol. 2001, 42, 1243-1257. [CrossRef] [PubMed]

94. Kohler, J.R.; Fink, G.R. Candida albicans strains heterozygous and homozygous for mutations in mitogen-activated protein kinase signaling components have defects in hyphal development. Proc. Natl. Acad. Sci. USA 1996, 93, 13223-13228. [CrossRef] [PubMed]

95. Leberer, E.; Harcus, D.; Broadbent, I.D.; Clark, K.L.; Dignard, D.; Ziegelbauer, K.; Schmidt, A.; Gow, N.A.; Brown, A.J.; Thomas, D.Y. Signal transduction through homologs of the Ste20p and Ste7p protein kinases can trigger hyphal formation in the pathogenic fungus Candida albicans. Proc. Natl. Acad. Sci. USA 1996, 93, 13217-13222. [CrossRef] [PubMed]

96. Shapiro, R.S.; Uppuluri, P.; Zaas, A.K.; Collins, C.; Senn, H.; Perfect, J.R.; Heitman, J.; Cowen, L.E. Hsp90 orchestrates temperature-dependent Candida albicans morphogenesis via Ras1-PKA signaling. Curr. Biol. 2009, 19, 621-629. [CrossRef] [PubMed]

97. Carlisle, P.L.; Kadosh, D. Candida albicans Ume6, a filament-specific transcriptional regulator, directs hyphal growth via a pathway involving Hgc1 cyclin-related protein. Eukaryot. Cell 2010, 9, 1320-1328. [CrossRef] [PubMed]

98. Zheng, X.D.; Lee, R.T.; Wang, Y.M.; Lin, Q.S.; Wang, Y. Phosphorylation of Rga2, a Cdc42 GAP, by CDK/Hgc1 is crucial for Candida albicans hyphal growth. EMBO J. 2007, 26, 3760-3769. [CrossRef] [PubMed]

99. Bishop, A.; Lane, R.; Beniston, R.; Chapa-y-Lazo, B.; Smythe, C.; Sudbery, P. Hyphal growth in Candida albicans requires the phosphorylation of Sec2 by the Cdc28-Ccn1/Hgc1 kinase. EMBO J. 2010, 29, 2930-2942. [CrossRef] [PubMed]

100. Caballero-Lima, D.; Sudbery, P.E. In Candida albicans, phosphorylation of Exo84 by Cdk1-Hgc1 is necessary for efficient hyphal extension. Mol. Biol. Cell 2014, 25, 1097-1110. [CrossRef] [PubMed]

101. Sinha, I.; Wang, Y.M.; Philp, R.; Li, C.R.; Yap, W.H.; Wang, Y. Cyclin-dependent kinases control septin phosphorylation in Candida albicans hyphal development. Dev. Cell 2007, 13, 421-432. [CrossRef] [PubMed]

102. Wang, H.; Huang, Z.X.; Au Yong, J.Y.; Zou, H.; Zeng, G.; Gao, J.; Wang, Y.; Wong, A.H.H.; Wang, Y. CDK phosphorylates the polarisome scaffold Spa2 to maintain its localization at the site of cell growth. Mol. Microbiol. 2016, 101, 250-264. [CrossRef] [PubMed]

103. Davis, D. Adaptation to environmental $\mathrm{pH}$ in Candida albicans and its relation to pathogenesis. Curr. Genet. 2003, 44, 1-7. [CrossRef] [PubMed]

104. Alvarez, F.J.; Konopka, J.B. Identification of an N-Acetylglucosamine Transporter That Mediates Hyphal Induction in Candida albicans. Mol. Biol. Cell 2007, 18, 965-975. [CrossRef] [PubMed]

105. Basso, V.; D’Enfert, C.; Znaidi, S.; Bachellier-Bassi, S. From Genes to Networks: The Regulatory Circuitry Controlling Candida albicans Morphogenesis. In Current Topics in Microbiology and Immunology; Springer: Berlin/Heidelberg, Germany, 2018; in press.

106. Albuquerque, P.; Casadevall, A. Quorum sensing in fungi a review. Med. Mycol. 2012, 50, 337-345. [CrossRef] [PubMed]

107. Hornby, J.M.; Jensen, E.C.; Lisec, A.D.; Tasto, J.J.; Jahnke, B.; Shoemaker, R.; Dussault, P.; Nickerson, K.W. Quorum sensing in the dimorphic fungus Candida albicans is mediated by farnesol. Appl. Environ. Microbiol. 2001, 67, 2982-2992. [CrossRef] [PubMed]

108. Hall, R.A.; Turner, K.J.; Chaloupka, J.; Cottier, F.; de Sordi, L.; Sanglard, D.; Levin, L.R.; Buck, J.; Mühlschlegel, F.A. The quorum-sensing molecules farnesol/homoserine lactone and dodecanol operate via distinct modes of action in Candida albicans. Eukaryot. Cell 2011, 10, 1034-1042. [CrossRef] [PubMed] 
109. Lu, Y.; Su, C.; Unoje, O.; Liu, H. Quorum sensing controls hyphal initiation in Candida albicans through Ubr1-mediated protein degradation. Proc. Natl. Acad. Sci. USA 2014, 111, 1975-1980. [CrossRef] [PubMed]

110. Polke, M.; Sprenger, M.; Scherlach, K.; Albán-Proaño, M.C.; Martin, R.; Hertweck, C.; Hube, B.; Jacobsen, I.D. A functional link between hyphal maintenance and quorum sensing in Candida albicans. Mol. Microbiol. 2017, 103, 595-617. [CrossRef] [PubMed]

111. Feng, Q.; Summers, E.; Guo, B.; Fink, G. Ras signaling is required for serum-induced hyphal differentiation in Candida albicans. J. Bacteriol. 1999, 181, 6339-6346. [PubMed]

112. Leberer, E.; Harcus, D.; Dignard, D.; Johnson, L.; Ushinsky, S.; Thomas, D.Y.; Schroppel, K. Ras links cellular morphogenesis to virulence by regulation of the MAP kinase and cAMP signalling pathways in the pathogenic fungus Candida albicans. Mol. Microbiol. 2001, 42, 673-687. [CrossRef] [PubMed]

113. Bar-Yosef, H.; Vivanco Gonzalez, N.; Ben-Aroya, S.; Kron, S.J.; Kornitzer, D. Chemical inhibitors of Candida albicans hyphal morphogenesis target endocytosis. Sci. Rep. 2017, 7, 5692. [CrossRef] [PubMed]

114. Naseem, S.; Araya, E.; Konopka, J.B. Hyphal growth in Candida albicans does not require induction of hyphal-specific gene expression. Mol. Biol. Cell 2015, 26, 1174-1187. [CrossRef] [PubMed]

115. Braun, B.R.; Head, W.S.; Wang, M.X.; Johnson, A.D. Identification and characterization of TUP1-regulated genes in Candida albicans. Genetics 2000, 156, 31-44. [PubMed]

116. Weissman, Z.; Kornitzer, D. A family of Candida cell surface haem-binding proteins involved in haemin and haemoglobin-iron utilization. Mol. Microbiol. 2004, 53, 1209-1220. [CrossRef] [PubMed]

117. Loeb, J.D.; Kerentseva, T.A.; Pan, T.; Sepulveda-Becerra, M.; Liu, H. Saccharomyces cerevisiae G1 cyclins are differentially involved in invasive and pseudohyphal growth independent of the filamentation mitogen-activated protein kinase pathway. Genetics 1999, 153, 1535-1546. [PubMed]

118. Rua, D.; Tobe, B.T.; Kron, S.J. Cell cycle control of yeast filamentous growth. Curr. Opin. Microbiol. 2001, 4, 720-727. [CrossRef]

119. Berman, J. Morphogenesis and cell cycle progression in Candida albicans. Curr. Opin. Microbiol. 2006, 9, 595-601. [CrossRef] [PubMed]

120. Bachewich, C.; Thomas, D.Y.; Whiteway, M. Depletion of a polo-like kinase in Candida albicans activates cyclase-dependent hyphal-like growth. Mol. Biol. Cell 2003, 14, 2163-2180. [CrossRef] [PubMed]

121. Bachewich, C.; Nantel, A.; Whiteway, M. Cell cycle arrest during S or M phase generates polarized growth via distinct signals in Candida albicans. Mol. Microbiol. 2005, 57, 942-959. [CrossRef] [PubMed]

122. Shi, Q.M.; Wang, Y.M.; Zheng, X.D.; Lee, R.T.; Wang, Y. Critical role of DNA checkpoints in mediating genotoxic-stress-induced filamentous growth in Candida albicans. Mol. Biol. Cell 2007, 18, 815-826. [CrossRef] [PubMed]

123. Bachewich, C.; Whiteway, M. Cyclin Cln3p links G1 progression to hyphal and pseudohyphal development in Candida albicans. Eukaryot. Cell 2005, 4, 95-102. [CrossRef] [PubMed]

124. Chapa y Lazo, B.; Bates, S.; Sudbery, P. The G1 cyclin Cln3 regulates morphogenesis in Candida albicans. Eukaryot. Cell 2005, 4, 90-94. [CrossRef] [PubMed]

125. Willems, A.R.; Schwab, M.; Tyers, M. A hitchhiker's guide to the cullin ubiquitin ligases: SCF and its kin. Biochim. Biophys. Acta 2004, 1695, 133-170. [CrossRef] [PubMed]

126. Sela, N.; Atir-Lande, A.; Kornitzer, D. Neddylation and CAND1 independently stimulate SCF ubiquitin ligase activity in Candida albicans. Eukaryot. Cell 2012, 11, 42-52. [CrossRef] [PubMed]

127. Trunk, K.; Gendron, P.; Nantel, A.; Lemieux, S.; Roemer, T.; Raymond, M. Depletion of the cullin Cdc53p induces morphogenetic changes in Candida albicans. Eukaryot. Cell 2009, 8, 756-767. [CrossRef] [PubMed]

128. Atir-Lande, A.; Gildor, T.; Kornitzer, D. Role for the SCFCDC4 ubiquitin ligase in Candida albicans morphogenesis. Mol. Biol. Cell 2005, 16, 2772-2785. [CrossRef] [PubMed]

129. Mendelsohn, S.; Pinsky, M.; Weissman, Z.; Kornitzer, D. Regulation of the Candida albicans Hypha-Inducing Transcription Factor Ume6 by the CDK1 Cyclins Cln3 and Hgc1. mSphere 2017, 2, 1-13. [CrossRef] [PubMed]

130. Woolford, C.A.; Lagree, K.; Xu, W.; Aleynikov, T.; Adhikari, H.; Sanchez, H.; Cullen, P.J.; Lanni, F.; Andes, D.R.; Mitchell, A.P. Bypass of Candida albicans Filamentation/Biofilm Regulators through Diminished Expression of Protein Kinase Cak1. PLoS Genet. 2016, 12, e1006487. [CrossRef] [PubMed]

131. Woolford, C.A.; Lagree, K.; Aleynikov, T.; Mitchell, A.P. Negative control of Candida albicans filamentationassociated gene expression by essential protein kinase gene KIN28. Curr. Genet. 2017, 63, 1073-1079. [CrossRef] [PubMed] 
132. Ofir, A.; Hofmann, K.; Weindling, E.; Gildor, T.; Barker, K.S.; Rogers, P.D.; Kornitzer, D. Role of a Candida albicans Nrm1/Whi5 homologue in cell cycle gene expression and DNA replication stress response. Mol. Microbiol. 2012, 84, 778-794. [CrossRef] [PubMed]

133. Chen, C.; Zeng, G.; Wang, Y. G1 and S phase arrest in Candida albicans induces filamentous growth via distinct mechanisms. Mol. Microbiol. 2018, 110, 191-203. [CrossRef] [PubMed]

134. Glory, A.; van Oostende, C.T.; Geitmann, A.; Bachewich, C. Depletion of the mitotic kinase Cdc5p in Candida albicans results in the formation of elongated buds that switch to the hyphal fate over time in a Ume6p and Hgc1p-dependent manner. Fungal Genet. Biol. 2017, 107, 51-66. [CrossRef] [PubMed]

135. Wolyniak, M.J.; Sundstrom, P. Role of actin cytoskeletal dynamics in activation of the cyclic AMP pathway and HWP1 gene expression in Candida albicans. Eukaryot. Cell 2007, 6, 1824-1840. [CrossRef] [PubMed]

136. Zou, H.; Fang, H.M.; Zhu, Y.; Wang, Y. Candida albicans Cyr1, Cap1 and G-actin form a sensor/effector apparatus for activating cAMP synthesis in hyphal growth. Mol. Microbiol. 2010, 75, 579-591. [CrossRef] [PubMed]

137. Douglas, L.M.; Martin, S.W.; Konopka, J.B. BAR domain proteins Rvs161 and Rvs167 contribute to Candida albicans endocytosis, morphogenesis, and virulence. Infect. Immun. 2009, 77, 4150-4160. [CrossRef] [PubMed]

138. Bar-Yosef, H.; Gildor, T.; Ramírez-Zavala, B.; Schmauch, C.; Weissman, Z.; Pinsky, M.; Naddaf, R.; Morschhäuser, J.; Arkowitz, R.A.; Kornitzer, D. A Global Analysis of Kinase Function in Candida albicans Hyphal Morphogenesis Reveals a Role for the Endocytosis Regulator Akl1. Front. Cell. Infect. Microbiol. 2018, 8, 17. [CrossRef] [PubMed]

139. Lu, Y.; Su, C.; Solis, N.V.; Filler, S.G.; Liu, H. Synergistic regulation of hyphal elongation by hypoxia, CO(2), and nutrient conditions controls the virulence of Candida albicans. Cell Host Microbe 2013, 14, 499-509. [CrossRef] [PubMed]

140. Braun, B.R.; Kadosh, D.; Johnson, A.D. NRG1, a repressor of filamentous growth in C. albicans, is down-regulated during filament induction. EMBO J. 2001, 20, 4753-4761. [CrossRef] [PubMed]

141. Lu, Y.; Su, C.; Liu, H. A GATA Transcription Factor Recruits Hda1 in Response to Reduced Tor1 Signaling to Establish a Hyphal Chromatin State in Candida albicans. PLoS Pathog. 2012, 8, e1002663. [CrossRef] [PubMed]

142. Bassilana, M.; Blyth, J.; Arkowitz, R.A. Cdc24, the GDP-GTP exchange factor for Cdc42, is required for invasive hyphal growth of Candida albicans. Eukaryot. Cell 2003, 2, 9-18. [CrossRef] [PubMed]

143. VandenBerg, A.L.; Ibrahim, A.S.; Edwards, J.E.; Toenjes, K.A.; Johnson, D.I. Cdc42p GTPase regulates the budded-to-hyphal-form transition and expression of hypha-specific transcripts in Candida albicans. Eukaryot. Cell 2004, 3, 724-734. [CrossRef] [PubMed]

144. Warris, A.; Ballou, E.R. Oxidative responses and fungal infection biology. Semin. Cell Dev. Biol. 2018. [CrossRef] [PubMed]

145. Nasution, O.; Srinivasa, K.; Kim, M.; Kim, Y.J.; Kim, W.; Jeong, W.; Choi, W. Hydrogen peroxide induces hyphal differentiation in Candida albicans. Eukaryot. Cell 2008, 7, 2008-2011. [CrossRef] [PubMed]

146. Rossi, D.C.P.; Gleason, J.E.; Sanchez, H.; Schatzman, S.S.; Culbertson, E.M.; Johnson, C.J.; McNees, C.A.; Coelho, C.; Nett, J.E.; Andes, D.R.; et al. Candida albicans FRE8 encodes a member of the NADPH oxidase family that produces a burst of ROS during fungal morphogenesis. PLoS Pathog. 2017, 13, 1-28. [CrossRef] [PubMed]

147. Koch, B.; Barugahare, A.A.; Lo, T.L.; Huang, C.; Schittenhelm, R.B.; Powell, D.R.; Beilharz, T.H.; Traven, A. A Metabolic Checkpoint for the Yeast-to-Hyphae Developmental Switch Regulated by Endogenous Nitric Oxide Signaling. Cell Rep. 2018, 25, 2244-2258.e7. [CrossRef] [PubMed]

148. Hromatka, B.S.; Noble, S.M.; Johnson, A.D. Transcriptional Response of Candida albicans to Nitric Oxide and the Role of the YHB1 Gene in Nitrosative Stress and Virulence. Mol. Biol. Cell 2005, 16, 4814-4826. [CrossRef] [PubMed]

149. Harcus, D.; Nantel, A.; Marcil, A.; Rigby, T.; Whiteway, M. Transcription Profiling of Cyclic AMP Signaling in Candida albicans. Mol. Biol. Cell 2004, 15, 4490-4499. [CrossRef] [PubMed]

150. Blank, H.M.; Callahan, M.; Pistikopoulos, I.P.E.; Polymenis, A.O.; Polymenis, M. Scaling of G1 Duration with Population Doubling Time by a Cyclin in Saccharomyces cerevisiae. Genetics 2018, 210, 895-906. [CrossRef] [PubMed]

(C) 2019 by the author. Licensee MDPI, Basel, Switzerland. This article is an open access article distributed under the terms and conditions of the Creative Commons Attribution (CC BY) license (http:/ / creativecommons.org/licenses/by/4.0/). 